\title{
Entrepreneurial orientation of startups: Research results
}

\author{
Jarosław Korpysa
}

\section{A B S T R A C T}

Objective: The main purpose of the paper is to establish which elements of entrepreneurial orientation (EO) have the biggest influence on the activities of Polish start-ups.

\begin{abstract}
Research Design \& Methods: The diagnosis was based on an analysis of individual components of entrepreneurial orientation and presentation of the results of research carried out by the author among 382 start-ups in Poland.
\end{abstract}

Findings: The research provide that, innovative activity of companies and exploring new market opportunities and possibilities by start-ups were important factors conditioning the operations and development of the companies studied. It is advisable to deepen the current theory of entrepreneurship orientation in relation to start-ups, understood as young innovative companies.

Contribution \& Value Added: The theoretical-empirical deliberations presented in the article may be a valuable source of information within the scope of the influence the particular elements of entrepreneurial orientation have on start-ups. However, for entrepreneurs they may be an impulse in the field of effective use of the elements of EO in the process of building competitiveness of young companies in Poland which is reflected in particular pillars of EO.

\begin{tabular}{ll}
\hline Article type: & research paper \\
Keywords: & entrepreneurial orientation; start-up; innovation; entrepreneur- \\
ship; innonations & L21, L26, L29 \\
\hline
\end{tabular}

\section{Suggested citation:}

Korpysa, J. (2019). Enterpreneurial orientation of startups: Research results. International Entrepreneurship Review (previously published as International Entrepreneurship / Przedsiębiorczość Międzynarodowa), 5(2), 37-51. https://doi.org/10.15678/IER.2019.0502.03

\section{INTRODUCTION}

The contemporary literature defines the entrepreneurial orientation (EO) as the ability of organizations to actively seek business opportunities and create strategies for companies operating on the market. Therefore, thanks to utilizing the entrepreneurial orientation, not only does the company shape the organization culture, but also intensifies its activity 
and competitive position by means of introducing new products, accessing new markets, introducing new models and business processes, or initiating systemic transformations (Amin, 2015). From such a perspective, the entrepreneurial orientation becomes an inextricable element of building a permanent competitive advantage of companies including, in particular, start-ups. The individual dimensions of entrepreneurial orientation connect and are intertwine, however, the results of research do not produce consistent results on the basis of which the influence of the particular pillars of EO on the activity of start-ups can be determined (Hayter, 2016; Hung Kee, \&Rahman, 2017; Tietz, 2013).

In view of the above characteristics, it is appropriate to present the research results concerning the particular elements of entrepreneurial orientation of start-ups in Poland. Therefore, the aim of the paper is to determine which elements of EO have the biggest influence on the activities of the Polish start-ups.

\section{LITERATURE REVIEW}

In the scholarly discourse, the entrepreneurial orientation serves as the basis of taking entrepreneurial actions which are connected with creating innovations, willingness to take risks and shaping market proactiveness by an economic unit (Charir, Primyastanto, \& Abidin, 2017). These three dimensions of the entrepreneurial orientation became the basis for scientists to carry out further research resulting in expanding the elements of the entrepreneurial orientation with additional pillars i.e. autonomy and competitive aggression (Nadhar, Tawe, \& Parawansa, 2017).

In analyzing the various dimensions of the entrepreneurial orientation it should be stated that the first component is innovativeness (Gloss, Pollack,\&Ward, 2017). This dimension is associated with Schumpeterian creative destruction. As a result of taking innovative actions, a new or upgraded product, service or technological process is created. As a consequence, it contributes to the situation where the innovative entity acquires productivity and efficiency which is higher in comparison with the remaining companies (Andersén, 2017; Khedhaouria, Gurău, \& Torrès, 2015). It also contributes to better financial results and increase in market share. Moreover, it is worth emphasizing that in the process of creating innovations, the effective use of tangible and intangible resources a given individual possesses plays an important role. It should be highlighted here that intangible resources (knowledge and experience) are the basis for the creation and realization of innovations (Fellnhofer, 2017). Thus a need to create and preserve certain norms, values, ways of thinking and acting in the organization, which will support the process of creating of new solutions becomes apparent. It is possible, among others, thanks to shaping the innovation culture which depends, inter alia, on the creativity of employees and owners of the company, flexibility in their operation, openness to change, analytical and synthetic thinking, or willingness to acquire new competence (Stuetzer et al., 2018).

Another important dimension of the entrepreneurial orientation is proactiveness, thanks to which the company may offer goods and services onto the market in advance, in comparison with the remaining competitors (Dai, Maksimov, Gilbert, \& Fernhaber, 2014). Therefore, ensuring that employees and owners of the company have the so called "entrepreneurial sensitivity", which forms the basis for recognizing and seizing business opportunities, is a key aspect. The concept of proactiveness as an element of entrepreneurial orientation differs from innovativeness above all by the fact that the company does 
not have to create new solutions but it is of utmost importance that it is the market leader who offers given goods and services as the first business entity (Lumpkin, \& Dess, 1996a). Thanks to this approach, the company will gain a competitive advantage (Cavusgil, \& Knight, 2015). A certain operationalization of the dimension of proactiveness of a company is carrying out research by the company concerning the formation of market needs in the future, ongoing training of employees and the owner of the company, as well as the entity possessing a strategy which is based on predicting future market trends (Fellnhofer, 2017).

The next element of entrepreneurial orientation is willingness to take risks, which is connected to taking decisions and actions without the knowledge of future results (Bogatyreva, Beliaeva, Shirokova, \& Puffer, 2017). In this regard, the willingness to take risks is characterized as the effect of innovativeness and proactiveness. This is mainly due to the fact that, a company introducing new solutions ought to carry out analysis in regard to future market requirements. Thereby, it takes a risk as it is unable to evaluate the effects of the measures taken. The same applies to involving human, physical and financial resources in realizing future undertakings which are connected with the unknown probability of success.

Competitive aggression is also a significant element of entrepreneurial orientation. It is reflected in the company taking actions aimed at bettering its own market position in relation to competition (Lumpkin, \& Dess, 1996a). It is possible due to constant analysis of the competitive environment in order to diagnose weak points of competitors, as well as setting up mechanisms reinforcing coopetition with competition or reinforcing strong competitive aggression (Mthanti, \& Ojah, 2017). At this point it should be emphasized that manifestations of coopetition are related, among others, to operation of a given company in clusters, technology and science parks, enterprise incubators. The company is thus capable of carrying out research and development work jointly with other entities. Moreover, as Hess and Rothaermel indicate, occurrences of coopetition may also be strategic alliances which allow entrepreneurs to share knowledge and also obtain know - know(Hess, \& Rothaermel, 2011).

The last aspect of entrepreneurial orientation is autonomy, understood as the capacity to independently explore and exploit market opportunities. The autonomy may be analyzed in the context of the entire organization or at the individual level (Al Mamun, Kumar, Ibrahim, \& Bin, 2017; Anderson, Covin \& Slevin 2009; Dada, 2018). In the first case, it is equated with its independence in relation to specific stakeholders connected to networks of business relationships. In the second case, it is usually analyzed based on the freedom of the performance of the particular tasks by employees. Owing to this, their creativity, motivation and responsibility for the entrusted tasks increase. In addition, the autonomy also conditions the flexibility of employees in action, which in turn leads to growth in the competitiveness of a company (Eshima \& Anderson, 2017; Martens, Machado, Martens, \& de Freitas, 2018; Yusoff, Al Mamun, Ibrahim, \& Hassan, 2018).

Numerous results of research have no consistent outcome which may be the basis for determining the influence of the particular pillars of entrepreneurial orientation on the activities of enterprises. It should be highlighted here that, there are discrepancies in the extent the influence of the particular elements of entrepreneurial orientation have of start-ups operations. Some research results show that all dimensions of entrepreneurial orientation influence, to a greater or lesser extent, the entrepreneurial construct of a start-up. However, others emphasize that only innovativeness, proactiveness and autonomy influence the en- 
trepreneurial construct whereas competitive aggression and risk- taking do not condition the entrepreneurial orientation of young companies (Covin,\& Lumpkin 2011).

Moreover, according to the author's research, no results in the field of the issues discussed relate to the start-ups operating in Poland. Therefore, the above characteristics fully justify the need to carry out research in the context of the influence of EO on the activities of start-ups.

In the contemporary scholarly discourse there are many definitions of start-ups. Blank defines the start-up as a temporary organization involved in the search for a scalable, replicable and profitable business model (Blank, \& Dorf, 2013). In this regard, a vital task for the start-up is to identify a proper business model, which will ultimately contribute to the rapid growth of an organization. Another definition is presented by Weissman who identifies a start-up as an entity operating on the market no longer than a year, which develops its product but does not sell it commercially (Wisseman, 2005). However, Skala characterizes a start-up as a small and young company which is starting its activity on the market of new technologies (Skala, 2016). This entity offers new technologically innovative products which have not been offered on the market so far. This definition is consistent with the definition of Reiss who analyzes start-ups through the prism of companies which create innovative solutions. From such a perspective, the principal characteristic of start-ups is their ability to create new value and extraordinary development. Moreover, the development of start-ups is not only possible due to a unique solution, which the company is offering onto the market but also thanks to an innovative management of the organization in the conditions of existing market uncertainty (Reiss, 2011).

With a view to realizing the objective of this paper, in further deliberations the startup definition convergent with the definitions of Weisssman and Reiss was adopted. Therefore, the start-up will be equated with a company operating no longer than a year, which offers an innovative solution.

\section{METHODOLOGY}

Due to the analyzed population, in the adopted empirical approach the incomplete enumerative induction was used. Its aim is the attempt to formulate certain laws and conclusions based on observations of a certain phenomenon happening in the context which is characterized by a space-time dimension (Apanowicz, 2005). Therefore, for verifying the cause-and-effect links taking place in start-ups it was decided to use mainly nomothetic approach. Out of the test procedures and methods proper for the analyzed approach the vetting was selected in which CAWI method was used. This choice was based on the fact that CAWI method is a good tool in the analysis of the niche of the research area which certainly in Poland includes the functioning of Polish start-ups. This tool allows a precise definition of the characteristics and qualities surveyed as well as efficient data collection due to the respondents having the feeling of anonymity and the possibility of participating in the study at a convenient time (Wójcicki, 2012).

In the study carried out (December 2017 - April 2018) an original questionnaire of online survey was used. It consisted of 23 proper questions, demographic information and diagnostic questions. In this regard, it is important that closed, semi-closed, conjunctive and disjunctive answer choices were used in the process of creating questions. EO was 
also measured using Likert's scale and the methods used in the research of Kuratko, Montagno, Hornsby (1990) and Dyduch (2008).

In this context, it is important to bear in mind that due to the lack of data, nonexistent in any available public registers, such as GUS, ZUS, marshal's office, voivodship office, commune office, concerning the start-ups, the diagnostic questions played an important role in determining the nature of the analyzed companies. These questions were created based on the accepted definition of a start-up which was presented in the theoretical part.

From the same sampling frame of the REGON register maintained by the Central Statistical Office (GUS) observations were selected for the sample. Therefore, using a procedure of simple random sampling, by means of the random sampling method, using stratified sampling, a database of 30,000 companies was drawn to whom invitations to take part in the research were sent by e-mail. There was a link in the e-mail which enabled access to the research survey. 409 start-ups were diagnosed in the quantitative study, from whom 382 duly completed research surveys were obtained.

While carrying out the empirical verification of the research results, appropriate accuracy and reliability of the measured values were checked in the first place using Cronbach's alpha coefficient. This indicator measures the cohesion within the scales, determining the extent to which the positions making up a given scale are similar to one another as well as whether they verify the same theoretical construct. The values of the coefficient range from 0 to 1 where the 0 value means absolutely unreliable measurement whereas 1 means perfectly reliable measurement. According to Nunnally's criterion (Nunnally \& Bernstein, 1967), the minimal value of Cronbach's alpha coefficient guaranteeing the reliability of a measurement should at least amount to 0,7. The detailed data concerning Cronbach's alpha coefficient for the research carried out were presented in the following table.

Table 1. Measurement of reliability of the research carried out

\begin{tabular}{|l|c|}
\hline \multicolumn{1}{|c|}{ Parts of the questionnaire } & Cronbach's alpha coefficient \\
\hline Innovative activity & 0.824485 \\
\hline Willingness to take risks & 0.732114 \\
\hline Proactiveness & 0.812123 \\
\hline Autonomy & 0.948565 \\
\hline Competitive aggression & 0.792912 \\
\hline Entity of the integrated questionnaire & 0.939281 \\
\hline
\end{tabular}

Source: own study.

On the basis of the data received it should be stated that Cronbach's alpha coefficient for the entity of the integrated questionnaire assumed the value higher than 0,9 which is a sign of high reliability of the research carried out. Moreover, while analyzing particular components of the questionnaire, relating to entrepreneurial orientation of the studied start-ups it may be stated that all selected factors were characterized by the reliability higher than the required minimum.

\section{The characteristics of sample}

Taking into account the sample structure divided in accordance with the company size criterion it must be stated that the majority of companies were micro-enterprises (52,32\%). Next, were small enterprises $(29,32 \%)$ and also medium-sized enterprises $(17,54 \%)$. The minority 
of companies were big enterprises $(0,82 \%)$. The criterion on SMEs were defined by definition of the European Commission (1996). Moreover is the number of medium-sized enterprises was definitely higher than in other studies. It was effects of conducting research in industrial - techno parks, where there are more mediums than small companies.

Taking into account the sample structure divided in accordance with the sector of activity criterion it should be noted that a significant proportion of companies operated in the service sector $(68,63 \%)$, one in five selected the commercial sector $(20,33 \%)$, whereas one in ten the manufacturing sector $(11,04 \%)$.

In the study of start-ups the location of the headquarters of a company was identified. The majority of the companies studied had their headquarters in the following voivodships: małopolskie $(13,82 \%)$, mazowieckie $(13,21 \%)$, śląskie $(9,21 \%)$ and dolnośląskie $(9,02 \%)$ and the least number in lubuskie $(1,41 \%)$ and podkarpackie $(2,17 \%)$.

The studied sample was also divided through the prism of generated annual income. The biggest number of entities $(37,24 \%)$ generated annual revenues of up to 700 thousand PLN. One in three entities $(33,92 \%)$ recorded a net income of up to 200 thousand PLN, and one in five $(20,32 \%)$ had total revenues ranging between 701 thousand PLN to 1.5 million PLN. The smallest number of companies (8,52\%) had annual income exceeding 1.5 million PLN.

In the study carried out, the start-up owners were characterized as well. The owners were a respondents. In majority of cases (72,32\%), these entities were run by men. Therefore, every fourth $(27,68 \%)$ entrepreneur was a woman. It is also worth mentioning that the population studied was also characterized by diversity in terms of age. The most numerous group $(49,43 \%)$ consisted of people under 30 years of age, as well as those in the 31 and 45 year old age bracket $(39,67 \%)$. The smallest group of respondents $(10,90 \%)$ were people aged over 45 .

To summarize, it should be stated that the average studied start-up was run by a man under 30 years of age. The entity operated in the service sector as a self-employment company. Moreover, in most cases the company had its headquarters in małopolskie, mazowieckie and śląskie voivodships, and generated annual income of up to 700 thousand PLN.

\section{Research results}

In the study carried out, the start-up owners were characterized as well. In majority of cases $(72,32 \%)$, these entities were run by men. Therefore, every fourth $(27,68 \%)$ entrepreneur was a woman. It is also worth mentioning that the studied sample was also characterized by diversity in terms of age. The most numerous group $(49,43 \%)$ consisted of people under 30 years of age, as well as those in the 31 and 45 year old age bracket $(39,67 \%)$. The smallest group of respondents $(10,90 \%)$ were people aged over 45 .

While evaluating the individual components of entrepreneurial orientation of startups, the innovativeness of the studied entities was diagnosed in the first place. According to the accepted definition of start-ups, only the companies which offered innovative solution on the market were part of the study. Therefore, it was appropriate to carry out an analysis concerning main determinants of innovative activities of start-ups.

It should be noted as a preliminary remark that the start-ups most often created product innovations $(62,52 \%)$, which chiefly consisted in introducing new or modified products, or ways of supplying services, which differed from the ones offered by these entities. Moreover one in three businesses indicated process innovations $(34,89 \%)$ which are most often connected with technological processes of manufacturing individual products using 
modern manufacturing methods, technology or equipment. The smallest number of companies created organizational $(12,42 \%)$ and marketing $(10,05 \%)$ innovations. The first of the listed, concern mainly introducing changes in the functioning of a company, i.e. changes in the method of managing it and organizing its work, whereas, the second relate to changes in designing a product, its packaging, promotion or price strategy.

The analysis of the main incentives for creating innovations by start-ups provides interesting outcomes. The data obtained indicate that in the group of the studied companies, the incentives related to creating innovations were of various character. The innovations were created chiefly by companies which possessed funding capacity of the work connected with creating new solutions $(77,82 \%)$ and also had access to research infrastructure $(61,28 \%)$. What is more, the willingness to create products of high quality $(61,13 \%)$ as well as employment of qualified staff $(47,11 \%)$ were also important drivers. Considering subsequent determinants it should be noted that every third enterprise created innovations out of the willingness to limit the risks connected with the activity as well as willingness to meet the needs of a client base. Among the presented determinants of creating innovations, the entrepreneurs ranked as lowest tax preferences $(2,38 \%)$ and possibility to use the resources of different enterprises (8,23\%).

In making further assessment of the level of innovativeness it was verified whether the enterprises are willing to implement innovations in the future i.e. within the next two years. In accordance with the outcomes it should be noted that the majority of them $(88,22 \%)$ intend to create innovations during the forthcoming period. $11,78 \%$ of the respondents were of the opposite view. Simultaneously, the respondents who want to implement innovations were asked to determine the type of the intended improvements. The largest number of the studied economic operators $(83,02 \%)$ intend to take measures connected with creating product innovation. One in three companies intends to create process innovations, while the similar percentage of businesses plan to create marketing $(10,05 \%)$ and organizational $(9,22 \%)$ innovations. Only $0,25 \%$ of the operators do not know what kind of innovations they will create in the future.

In further research process another element of the orientation was diagnosed, i.e. proactiveness of an enterprise. In this respect, a diagnosis in the scope of start-ups searching for new business opportunities on the market, permanent personnel training, as well as possessing and utilizing a strategy in the conducted activities was carried out.

Starting from the assumption that the activity of any company is based on setting and then realizing strategic objectives, a question concerning the company having a mission and strategy was asked to the respondents at the beginning. According to the outcomes obtained it should be stated that $58,23 \%$ of companies had a mission and strategy. However, in majority they were not written in the form of a document. Therefore, $41,77 \%$ of the companies studied declared that they do not have a mission nor strategic objectives. Among this group three quarters of the companies do not intend to develop a mission or strategy in the future.

In the following stage of the diagnosis, the analysis concerning the identification of new business opportunities and permanent personnel training reflected in the process of locating knowledge was made. In assessing the degree of locating knowledge it should be stated that in majority, the businesses identified the needs of the present condition and gaps in knowledge and technology. Most frequently, among the internal sources of acquir- 
ing knowledge, the information obtained directly from employees dominated. They also based on the knowledge of the owners $(82,32 \%)$. The process of evaluating current industrial potential was less important $-30,63 \%$ (so called technological audit).

In the context of verifying the external sources of knowledge absorption it should be noted that the information obtained directly from clients $(55,13 \%)$ dominated. Moreover, the entrepreneurs acquired knowledge through a study of the condition of their competition, utilizing, as a basic source of information, the participation in fairs, the Internet as well as meetings with clients and suppliers (50,68\%).

The outcome of the process of locating knowledge was, among others, the participation of owners or workers in trainings and courses as well as research projects. On the basis of the results, it has to be concluded that over a half of the companies surveyed declared that owners or workers participated in trainings/courses, one in four entities was involved in implementation of research projects.

When assessing another element of entrepreneurial orientation - competitive aggression, the entrepreneurs were asked to specify the factors conditioning the competitive advantage of start-ups. According to the data obtained it may be stated that among relevant factors which condition the competitiveness of the companies studied, one can enumerate: product quality $(38,94 \%)$, qualified staff $(38,69 \%)$, flexibility to adjust the offer to the needs of clients $(37,82 \%)$, and innovativeness $(24,47 \%)$. Carrying out research and development $(15,57 \%)$ and technological advancement $(13,53 \%)$ are of moderate significance. However, among the factors of minor importance were company size $(35,60 \%)$, and the time of existence on the market $(32,12 \%)$.

Besides diagnosing the factors conditioning the competitiveness of business, the respondents were asked to give answers to the questions concerning actions for improving the market position. The results are presented in the following table.

Table 2. Competitive aggression

\begin{tabular}{|l|c|c|}
\hline \multicolumn{1}{|c|}{ Specification } & Yes & No \\
\hline The company continually strives to improve its position in relation to its competitors & $79.23 \%$ & $20.77 \%$ \\
\hline The company strives for rivalry with competitors & $89.37 \%$ & $10.63 \%$ \\
\hline $\begin{array}{l}\text { The company conducts analysis on the functioning of the competition for diagnos- } \\
\text { ing the sources of competitive advantage }\end{array}$ & $34.51 \%$ & $65.49 \%$ \\
\hline
\end{tabular}

Source: own study.

According to the information provided, it must be stated that a vast majority of companies strive to improve their market position and constantly competes with competitors. Unfortunately, only one in three companies conducts analysis on the functioning of the competition which may be the result of the fact that businesses are in the development stage and thus are more focused on strengthening their own competitive position than assessing the competition.

In further research process, willingness of start-ups to take risks was evaluated. At the beginning, the respondents were asked to specify the main sources of financing their business activities. A vast majority of start-ups (91,32\%) are financed by own resources, only $5,32 \%$ of companies fund their operations with EU funds, while 3,36\% of companies with loans and borrowings. As the primary reason for financing their operations by own resources, the entrepreneurs enumerated, above all, difficulties with finding external 
funding in the start-up phase. They are connected with the lack of financial credibility and reluctance of banks to grant a loan or credit for start-ups as well as the absence of EU financing programs supporting start-ups. Another reason often given by the entrepreneurs was willingness to limit the risk connected with the necessity of returning the acquired financing in case of the enterprise failure.

In analyzing the willingness of start-ups to take risks, it was evaluated to what extent the entrepreneurial characteristic of the owners of the companies studied, i.e. willingness to take risks, influences the functioning of the businesses studied. To determine the relevance of the characteristic studied, a five grade scale of Likerat was used. According to the data collected, $63,42 \%$ of entrepreneurs claim that this characteristic has a great impact on the functioning of start-ups. One in four respondents $(24,89 \%)$ stated that it is of significant influence, $5,74 \%$ described the influence as moderate, $4,56 \%$ as of little importance. Only 1,39\% of the surveyed claimed that the characteristic is insignificant from the point of view of the business operations.

During the research process another element of entrepreneurial orientation i.e. autonomy which is reflected in the ability of companies to independently explore and harness market opportunities was diagnosed. For this purpose, the respondents were asked to determine the extent of independence in their exploration of business opportunities. On the basis of the results obtained it is concluded that $92,34 \%$ of companies stated no limits and interventions of external stakeholders in exploration of business opportunities. Only $7,66 \%$ of start-ups declared the existence of certain limitations, which mainly resulted from franchise and license agreements signed.

In the next stage of entrepreneurial orientation analysis of start-ups the entrepreneurs were also asked to evaluate the particular components of entrepreneurial orientation on a scale from 1 to 7 (where 1 meant that the respondent totally disagrees with a statement and 7 meant that he agrees completely). In the research were used a methods of Kuratko, Montagno, Hornsby (1990) and Dyduch (2008). The average study outcome was presented in the following table.

Taking into account the particular elements of entrepreneurial orientation it should be stated that the average results indicate that two elements, i.e. innovativeness and proactiveness, impact most seriously on EO. The remaining components of EO are characterized by moderate degree of impact. In this respect, in assessing the level of innovativeness and proactiveness of companies it should be stated that the owners of start-ups emphasize that the process of exploiting innovative business opportunities, the actual creation and sales of innovations, as well as implementing innovations within the organization are of key importance in the carried out activities.

Strategic management is also important as well as lifelong learning of the staff and constantly seeking new ideas. However, risk-taking in the activities, rivalry with competitors and using competitive advantages by business entities do not influence the functioning and development of start-ups in a very significant way.

At the final stage of the study of entrepreneurial orientation, an evaluation of the influence the particular elements of entrepreneurial orientation i.e. innovation, willingness to take risks, proactiveness, competitive aggression and autonomy have on the functioning effectiveness of the companies studied was carried out. At this point it is important to bear in mind that the effectiveness was studied through the prism of trends in the devel- 
opment of the following values: profit of the company, number of clients and number of products and services offered. However, for the identification of stochastic dependency between the elements of entrepreneurial orientation and functioning effectiveness of the companies Cramér's V coefficient and an independence test were used.

Table 3. The component elements of entrepreneurial orientation of a company

\begin{tabular}{|c|c|}
\hline The component elements of entrepreneurial orientation & Scale \\
\hline \multicolumn{2}{|l|}{ Risk-taking } \\
\hline The specific nature of the activity requires taking permanent risk & 3.23 \\
\hline $\begin{array}{l}\text { Management takes risky decisions of uncertain consequences, involving a substantial amount } \\
\text { of resources and assets }\end{array}$ & 3.01 \\
\hline \multicolumn{2}{|l|}{ Innovativeness } \\
\hline The company is oriented towards unceasing introduction of new products and services & 5.98 \\
\hline $\begin{array}{l}\text { Within the last three years the company introduced innovations in the offered products and } \\
\text { services }\end{array}$ & 6.63 \\
\hline The company is oriented towards harnessing business opportunities & 6.29 \\
\hline \multicolumn{2}{|l|}{$\begin{array}{ll}\text { Proactiveness } \\
\end{array}$} \\
\hline The company has an activity strategy which is based on predicting future market trends & 6.38 \\
\hline The company actively seeks new market opportunities & 6.97 \\
\hline There is a need and willingness to develop new ideas in the organization & 6.27 \\
\hline The company places significant emphasis on lifelong learning of the staff & 5.02 \\
\hline \multicolumn{2}{|l|}{ Competitive aggression } \\
\hline The company is constantly striving to improve its market position in relation to its competitors & 2.61 \\
\hline The company is striving for rivalry with competitors & 2.38 \\
\hline $\begin{array}{l}\text { The company is carrying out analyses concerning the functioning of competitors in order to } \\
\text { diagnose the sources of the competitive advantage. }\end{array}$ & 3.94 \\
\hline
\end{tabular}

Source: own study.

Considering the innovative activity of start-ups it ought to be stated that for all the studied indicators of functioning effectiveness of the companies, the existence of a strong correlation was diagnosed (Cramér's V coefficient exceeding 0,6). Similar results were obtained in case of another component of entrepreneurial orientation, i.e. proactiveness. For all the remaining elements of entrepreneurial orientation i.e. willingness to take risks, competitive aggression and autonomy the existence of a moderate or weak correlation was demonstrated (Cramér's $V$ coefficient below 0,4 ) in the context of dynamics of profit, number of clients and number of products and services. Moreover, it should be noted that, among all the elements of entrepreneurial orientation, innovativeness and proactiveness influence the increase of the effectiveness factors of start-ups to greatest extent. In this respect, it is worth mentioning that innovativeness influences the increase in the number of new products and services most and rise in profit least. However, in case of proactiveness, this element of entrepreneurial orientation has the biggest influence on the rise in profit, however, the smallest on the increase in new clients. It is worth noting that all the elements of entrepreneurial orientation have very limited effects on the decrease of profit, number of clients, or number of new products and services, thereby contributing to ensuring stability and growth of start-ups.

In view of the outcomes obtained it should be stated that the companies creating innovations, willing to take risks and harnessing the sources of competitive advantage, such 
as: innovativeness, quality of products, qualified staff, company's image, more often register an improvement in net profit, number of clients, and number of products and services compared with companies not creating innovations, less willing to take risks and utilizing the sources of competitive advantage to lesser extent.

Table 4. Correlation between the elements of entrepreneurial orientation and performance indicators of start - ups functioning

\begin{tabular}{|c|c|c|c|c|}
\hline \multirow{2}{*}{\multicolumn{2}{|c|}{ Specification }} & Decrease & Constant level & Increase \\
\hline & & \multicolumn{3}{|c|}{ Dynamics of profit in $2015-2017$} \\
\hline Innovativeness & $\begin{array}{l}p=0,000000 \\
V=0,638921\end{array}$ & $13,82 \%$ & $25,22 \%$ & $60,96 \%$ \\
\hline Proactiveness & $\begin{array}{l}p=0,000000 \\
V=0,728367\end{array}$ & $4,73 \%$ & $31,72 \%$ & $63,55 \%$ \\
\hline Willingness to take risks & $\begin{array}{l}p=0,000000 \\
V=0,182911\end{array}$ & $6,74 \%$ & $50,11 \%$ & $43,15 \%$ \\
\hline Competitive aggression & $\begin{array}{l}p=0,000000 \\
V=0,239521\end{array}$ & $26,28 \%$ & $35,88 \%$ & $37,84 \%$ \\
\hline Autonomy & $\begin{array}{l}p=0,000000 \\
V=0,196382\end{array}$ & $23,35 \%$ & $40,19 \%$ & $36,48 \%$ \\
\hline \multicolumn{5}{|c|}{ Number of new clients in $2015-2017$} \\
\hline Innovativeness & $\begin{array}{l}p=0,000000 \\
V=0,673451\end{array}$ & $5,18 \%$ & $32,07 \%$ & $62,75 \%$ \\
\hline Proactiveness & $\begin{array}{l}p=0,000000 \\
V=0,62593\end{array}$ & $11,05 \%$ & $29,63 \%$ & $59,32 \%$ \\
\hline Willingness to take risks & $\begin{array}{l}p=0,000000 \\
V=0,237411\end{array}$ & $23,81 \%$ & $37,98 \%$ & $38,21 \%$ \\
\hline Competitive aggression & $\begin{array}{l}p=0,000000 \\
V=0,123721\end{array}$ & $36,54 \%$ & $29,54 \%$ & $33,92 \%$ \\
\hline Autonomy & $\begin{array}{l}p=0,000000 \\
V=0,196382\end{array}$ & $24,04 \%$ & $38,51 \%$ & $37,45 \%$ \\
\hline \multicolumn{5}{|c|}{ Number of new products and services in $2015-2017$} \\
\hline Innovativeness & $\begin{array}{l}p=0,000000 \\
V=0,122344\end{array}$ & $5,37 \%$ & $8,92 \%$ & $85,71 \%$ \\
\hline Proactiveness & $\begin{array}{l}p=0,000000 \\
V=0,112311\end{array}$ & $0,93 \%$ & $35,61 \%$ & $63,46 \%$ \\
\hline Willingness to take risks & $\begin{array}{l}p=0,000000 \\
V=0,157355\end{array}$ & $8,34 \%$ & $39,32 \%$ & $52,34 \%$ \\
\hline Competitive aggression & $\begin{array}{l}p=0,000000 \\
V=0,174719\end{array}$ & $5,24 \%$ & $42,78 \%$ & $51,98 \%$ \\
\hline Autonomy & $\begin{array}{l}p=0,000000 \\
V=0,163212\end{array}$ & $10,26 \%$ & $43,21 \%$ & $46,53 \%$ \\
\hline
\end{tabular}

Source: own study.

\section{CONCLUSIONS}

Based on the outcomes obtained it should be stated that the particular elements of entrepreneurial orientation condition the functioning and development of Polish start-ups. Therefore, it was diagnosed that the companies studied create product and process innovations 
most often, and that their main incentive for innovative activity is to have a possibility of financing the works connected with creating innovations and access to research infrastructure. In addition, it was determined that start-ups constantly explore new business opportunities on the market by means of analyzing needs of clients, analyzing competition or assessing their own intellectual and technological potential. It was also determined that startups harness the sources of competitive advantage which are reflected in the quality of products offered, product innovativeness or flexibility of adapting to the client's needs. What is more, it was diagnosed that the start-ups are characterized by quite substantial willingness to take risks and independence in exploring and using business opportunities.

In the course of research, the analysis of the stochastic relationships between the individual elements of entrepreneurial orientation and functioning effectiveness of Polish start-ups was completed. It may be stated that innovative activity of companies and exploring new market opportunities and possibilities by start-ups were important factors conditioning the operations and development of the companies studied. In this regard, the development of innovative start-ups, which may contribute to strengthening the competitiveness of the small and medium-sized enterprises sector and faster transition of Polish economy into the economy 4.0 is particularly important.

Taking into account all the above findings it should be stated that in spite of meeting the requirements of the paper, the subject certainly has not yet been exhausted. In this respect certain limitations of the research carried out resulting, among other things, from evaluating only the opinions of company owners should be underlined. The studies obviously require follow-up including quantitative analyses carried out on a bigger sample. Despite this imperfection, the most important elements which influence the activity of startups in Poland have been diagnosed. Therefore, the results may be useful in creating and developing start-ups in Poland.

\section{REFERENCES}

Al Mamun, A., Kumar, N., Ibrahim, M.D., \& Bin, M.N.H. (2017). Validating the Measurement of Entrepreneurial Orientation. Economics \& Sociology, 10(4), 51-66.

Amin, M. (2015). The effect of entrepreneurship orientation and learning orientation on SMEs' performance: an SEM-PLS approach. Journal for International Business and Entrepreneurship Development, 8(3), 215-230.

Andersén, J. (2017). What about the employees in entrepreneurial firms? A multi-level analysis of the relationship between entrepreneurial orientation, role ambiguity, and social support. International Small Business Journal, 35(8), 969-990.

Anderson, B.S., Covin, J.G., \& Slevin, D.P. (2009). Understanding the relationship between entrepreneurial orientation and strategic learning capability: an empirical investigation. Strategic Entrepreneurship Journal, 3(3), 218-240.

Apanowicz, J. (2005). Metodologiczne uwarunkowania pracy naukowej: prace doktorskie, prace habilitacyjne. Warszawa: Difin.

Blank, S., \& Dorf, B. (2013). Podręcznik startupu. Budowa wielkiej firmy krok po kroku. Gliwice: Helion.

Bogatyreva, K., Beliaeva, T., Shirokova, G., \& Puffer, S.M. (2017). As different as chalk and cheese? The relationship between entrepreneurial orientation and SMEs' growth: evidence from Russia and Finland. Journal of East-West Business, 23(4), 337-366. 
Cavusgil, S.T., \& Knight, G. (2015). The born global firm: An entrepreneurial and capabilities perspective on early and rapid internationalization. Journal of International Business Studies, 46(1), 3-16.

Charir, N.A., Primyastanto, M., \& Abidin, Z. (2017). Effect of Marketing Knowledge Competency and Entrepreneurship Orientation on Marketing Capabilities and Marketing Performance of Fishery Smes in Malang City, East Java. ECSOFiM (Economic and Social of Fisheries and Marine), 5 (1), 53-67.

Covin, J.G., Lumpkin, G.T. (2011). Entrepreneurial orientation theory and research: Reflections on a needed construct. Entrepreneurship theory and practice, 35(5), 855-872.

Dada, O. (2018). A model of entrepreneurial autonomy in franchised outlets: a systematic review of the empirical evidence. International Journal of Management Reviews, 20(2), 206-226.

Dai, L., Maksimov, V., Gilbert, B. A., \& Fernhaber, S.A. (2014). Entrepreneurial orientation and international scope: The differential roles of innovativeness, proactiveness, and risk-taking. Journal of Business Venturing, 29(4), 511-524.

Dyduch, W. (2008). Pomiar przedsiębiorczości organizacyjnej. Prace Naukowe/Akademia Ekonomiczna w Katowicach, Katowice: UE Katowice.

European Commission. (1996). The proposal of the European Commission from April 3rd, 1996 concerning the definition of the small and medium enterprises (96/280/EC),

Eshima, Y., \& Anderson, B.S. (2017). Firm growth, adaptive capability, and entrepreneurial orientation. Strategic Management Journal, 38(3), 770-779.

Fellnhofer, K. (2017). Drivers of innovation success in sustainable businesses. Journal of Cleaner Production, 167, 1534-1545.

Gloss, A., Pollack, J.M., \& Ward, M.K. (2017). A risky shift? An exploration of the measurement equivalence of entrepreneurial attitudes and entrepreneurial orientation across socioeconomic gradients. Journal of Business Venturing Insights, 7, 32-37.

Hayter, C.S. (2016). A trajectory of early-stage spinoff success: the role of knowledge intermediaries within an entrepreneurial university ecosystem. Small Business Economics, 47(3), 633-656.

Hess, A.M., \& Rothaermel, F.T. (2011). When are assets complementary? Star scientists, strategic alliances, and innovation in the pharmaceutical industry. Strategic Management Journal, 32 (8), 895-909.

Hung Kee, D.M., \& Rahman, N.A. (2017). Analyzing entrepreneurial orientation impact on start- up success with support service as moderator: A PLS-SEM approach. Business and Economic Horizons, 13(2), 128-141.

Khedhaouria, A., Gurău, C., \& Torrès, O. (2015). Creativity, self-efficacy, and small-firm performance: the mediating role of entrepreneurial orientation. Small Business Economics, 44(3), 485-504.

Kuratko, D.F., Montagno, R.V., \& Hornsby, J.S. (1990). Developing an intrapreneurial assessment instrument for an effective corporate entrepreneurial environment. Strategic management journal, 11, 49-58.

Lumpkin, G. T., \& Dess, G. G. (1996a). Clarifying the entrepreneurial orientation construct and linking it to performance. Academy of management Review, 21(1), 135-172.

Lumpkin, G.T., \& Dess, G.G. (1996b). Enriching the entrepreneurial orientation construct-a reply to "entrepreneurial orientation or pioneer advantage", The Academy of Management Review, 21 (3), 605-607.

Martens, C.D.P., Machado, F.J., Martens, M.L., \& de Freitas, H.M.R. (2018). Linking entrepreneurial orientation to project success. International Journal of Project Management, 36(2), 255-266.

Mthanti, T., \& Ojah, K. (2017). Entrepreneurial orientation (EO): Measurement and policy implications of entrepreneurship at the macroeconomic level. Research Policy, 46(4), 724-739. 
Nadhar, M., Tawe, A., \& Parawansa, D.A. (2017). The Effect of Work Motivation and Entrepreneurship Orientation on Business Performance through Entrepreneurial Commitments of Coffee Shops in Makassar. International Review of Management and Marketing, 7(1), 470-474.

Nunnally, J. C., \& Bernstein, I. H. (1967). Psychometric Theory. New York: McGraw-Hill Inc.

Reiss, E.(2011). The Lean Startup, Crown Business.

Skala, A. (2016). Statement on the first research on digital startups in Poland. International Entrepreneurship / Przedsiębiorczość Międzynarodowa, 2(2), 191-202.

Stuetzer, M., Audretsch, D.B., Obschonka, M., Gosling, S.D., Rentfrow, P.J., \& Potter, J. (2018). Entrepreneurship culture, knowledge spillovers and the growth of regions. Regional Studies, 52(5), 608-618.

Tietz, R. (2013). Executive Teams in Research-based Spin-off Companies: An Empirical Analysis of Executive Team Characteristics, Strategy, and Performance. St. Gallen, Switzerland: Springer.

Wisseman, J. G. (2005). Technostarterzy: dlaczego i jak?. Polska Agencja Rozwoju Przedsiębiorczości, Warszawa: PARP.

Wójcicki, T. (2012). Application of the CAWI method for the holistic support of innovation transfer to business practice. Problemy Eksploatacji, 4, 175-186.

Yusoff, M.N.H.B., Al Mamun, A., Ibrahim, M.D., \& Hassan, H. (2018). Measuring and comparing functional business skills and knowledge among Asnaf community in Malaysia. Economics \& Sociology, 11(2), 229-247. 


\section{Author}

\section{Jaroslaw Korpysa}

Hab. PhD prof. US, is employed at the Department of Microeconomics, Faculty of Economics and Management, Szczecin University (Poland).Korpysa has published articles and delivered a lot of conference presentations about entrepreneurship, spin of companies, inequalities in the labour market and strategic analysis of companies. He was a follower of 7th and 6th FP, Human Resources and Mobility Activity, Marii Curie Action at University of Vilnius (Lithuania), University of St. Gallen (Switzerland) and IWEIR, National Academy of Sciences of Ukraine.

Correspondence to: prof. US, dr hab. Jarosław Korpysa, Faculty of Economics and Management University of Szczecin, Mickiewicza 64 Str. 71-101 Szczecin, Poland e:mail: jaroslaw.korpysa@usz.edu.pl

ORCID (i) http://orcid.org/0000-0002-2400-3308

\section{Acknowledgements and Financial Disclosure}

The project is financed within the framework of the program of the Minister of Science and Higher Education under the name "Regional Excellence Initiative" in the years 2019-2022, project number 001/RID/2018/19, the amount of financing PLN 10,684,000.00.

\section{Copyright and License}

(1) (1) $\Theta$

This article is published under the terms of the Creative Commons

Attribution - NoDerivs (CC BY-ND 4.0) License

http://creativecommons.org/licenses/by-nd/4.0/

Published by the Centre for Strategic and International Entrepreneurship - Krakow, Poland

The journal is co-financed in the years 2019-2020 by the Ministry of Science and Higher Education of the Republic of Poland in the framework of ministerial programme "Support for Scientific Journals" (WCN) on the basis of contract no. 238/WCN/2019/1 concluded on 15 August 2019. 
